\title{
THE PROPOSE GOVERNANCE FRAMEWORK FOR SHARIAH CORPORATION
}

\author{
Hartinie Abd Aziz ${ }^{1}$ \\ Faculty of Law and International Relations, UNISZA \\ (Email: hartinieabdaziz@gmail.com) \\ Zuhairah Ariff Abd Ghadas ${ }^{2}$ \\ Faculty of Law and International Relations, UNISZA \\ (Email: zuhairahariff@unisza.edu.my)
}

Accepted date: $22-02-2019$

Published date: 10-07-2019

To cite this document: Abd Aziz, H. \& Abd Ghadas, Z. A. (2019). The Propose Governance Framework for Shariah Corporation. International Journal of Law, Government and Communication, 4(15), 84-90.

DOI: $10.35631 / \mathrm{ijlgc} .415009$

\begin{abstract}
Shariah Corporation has developed rapidly offering a various product and services that comply with the shariah principles. Nevertheless, all the so called shariah corporation was framed under conventional framework beginning from its incorporation as a company up until its corporate governance, and decision's making process. Such conventional framework does differ from the shariah framework. Hence, it is a need to develop a new framework of governance that can be applied to all shariah corporations. This is mainly because the objective of the conventional and the Islamic Corporate governance is different as conventional corporate governance structure is more focused on the protection of the rights of the stakeholders; while Islamic corporate governance focus on retaining the Islamicity of whole corporation This paper emphasizes that Shari'ah compliance is the core element of shariah corporation and thus Shariah governance is an ideal platform to ensure such adherence and thus boost up the level of public confidence in shariah corporation. It is undeniably that, there are few shariah governance codes available nowadays, but, these codes are mainly referred to Islamic financial institution per se. This study looks at the current conventional framework and accordingly, this paper proposes a Shari'ah governance framework to accommodate the shariah corporation. The framework suggests incorporating various fundamental governance principles of organisations. This proposed framework is to strengthen the existing guidelines and reflect a holistic governance system for shariah corporation.
\end{abstract}

Keywords: Corporate Governance, Shariah Governance, Shariah Corporation, Shura, Hisbah, Shariah Supervision

\section{Introduction}

With the recent and rapid development of shariah business entities, there is a need to look into a suitable governance framework for Shariah Corporation to ensure that all business 
activities of the company complied with the Shariah principles. According to Rusni, "a corporation needs to have a shari'ah compliant corporate governance structure in order for it to be an Islamic corporation" (Muneeza \& Hassan, 2014). In Islamic corporation, the compliance principles must be strictly observed and thus, requires a special governance framework which is called Shari'ah code of governance, upon which a special supervisory body is to be appointed to monitor the related business activities to be compliant with the Shari'ah principles.

This paper aims to highlight a proposal of Shari'ah governance framework for Shariah Corporation. It is structured into several sections; following this introduction, the next section states briefly the methodology used. The third section is basically the literature reviews which further outline the central themes of this research by highlighting the need of shariah governance for Shariah Corporation and the comparison between conventional governance. The fourth section will explain on the proposed recommendations and lastly, the final section summarizes the contribution and implications that this paper has given.

\section{Research Method}

This paper is based on doctrinal analysis utilizing qualitative research method. The methodology embraced in this research comprises of theoretical literatures of both primary data such as legislations relevant to Shariah Corporation in Malaysia and secondary data which is the major reference in this paper.

\section{Literature Review}

\section{Corporate Governance in Conventional Companies}

Corporate governance is very vital in every organization, because good corporate governance contribute to better firm performance, thus, it is expected for every other organization to enforce corporate governance policy(Fauziah, Yusoff, \& Alhaji, 2012). Corporate governance emphasized on the moral and ethical dimensions of managing a company's business. Good corporate governance enhances the reputation of an organization and become more attractive to customers, investors and suppliers. Three underlying principles of corporate governance are accountability, transparency and trustworthiness. The process of corporate governance focusses on directing and the business and affairs of the company towards enhancing business prosperity and corporate accountability with the ultimate objective of realising long-term shareholder value, whilst taking into account the interest of other stakeholders (MICG, 2012).

According to Zulkifli Hassan as cited in Rashidah \& Rizal, "there are many models of conventional corporate governance. Each structure has its own attributes, signifies special corporate models and different objectives of corporation"(Rashidah Abdul Rahman and Mohammad Rizal Salim, 2010). The conventional corporate governance models differ from country to country and region to region. This is evident from the work of Malekian and Daryaei (2010), where they have categorised conventional corporate governance to AngloSaxon countries, Germanic Countries, Latin Countries and Japan. Lewis (2005) has classified conventional corporate governance on decision-making basis. He has classified conventional corporate governance to "managed corporation model"' and "socially responsive model" (Lewis, 2005).

Corporate governance involves a set of relationships between a company's management, its board, its shareholders and other stakeholders in determining the direction and performance 
of corporations. It ensures that the board of directors is accountable for the pursuit of corporate objectives and that the corporation itself conforms to the law and regulations. Corporate governance is one key element in improving economic efficiency and growth as well as enhancing investor confidence. Corporate governance also provides the structure through which the objectives of the company are set, and the means of attaining those objectives and monitoring performance are determined. (Choudhury \& Hoque, 2013; OECD, 2004)

\section{Shariah Corporation}

In Malaysia all companies are regulated under the Companies Act 2016. The Act was based on the common law principles which entail companies as a legal entity with rights and attributes of a body corporate. Under the common law, a corporation as a non-human entity has rights as a legal person (Fitzgeral, 1966). According to Keenan and Bisacre as noted in Zuryati, 'A corporation is a succession or collection of persons having at law an existence, rights and duties, separate and distinct from those of the persons who are from time to time its members(Zuryati, Azrae, \& Yusoff, 2009). The legal effect of recognition a corporate body as an entity is that, once a company has been incorporated, it will be considered as 'a person'. The corporation inter alia has the right to sue and to be sued, own property in its name and it is separate from the owner or shareholders of the corporation(Zuryati et al., 2009). It should be noted that, Shariah corporate structure is not similar with the conventional structure. The legal framework for the Shariah Corporation should covers all the requirements such as, maqasid shariah as the basis of business framework, the legality of business entities as well as shariah good governance.

There are several shari'ah governance codes or guidelines issued specifically for Islamic Financial Institutions by several countries such as Malaysia and organisations or institutions (like AAOIFI and IFSB). But the problem with these regulations or rules is that first; it is not applicable to Islamic corporations in general; and second; it is not binding to the whole world and it cannot be uniformly adopted and applied to all the Islamic corporations. Hence, it is a need to develop a standard code of shariah governance to all Islamic corporations; irrespective of their locality.(Muneeza \& Hassan, 2014)

\section{Governance in Islamic Companies}

The framework for Shariah Corporation is different from conventional corporation framework because of the Shariah principles compliant issues. The model of shariah compliant business must be focusing on at least five aspects of business entities: the functions of management, the process of business, corporate culture, corporate governance, and corporate social responsibility(Febianto, 2011). The governance is a must component to be scrutinised in the shariah corporation framework.

It is observed that the basis of any principles in Islam is the concept of Tawhid i.e. Oneness of God or full submission to God and the concept of Tawhid is said to be the foundation of corporate governance in Islam(Alam Choudhury \& Ziaul Hoque, 2006). Full submission to the Creator will lead a person to comply fully with the teachings of Islam and when the business activities are broadly inspired and guided by the concept of Tawhid, explicitly the positive values are adopted, and negative values are avoided in the business. Thus, Tawhid has been described as the premise of corporate governance in Shariah

Besides, in Islam, Muslims are encouraged to participate actively in business activities for the development of the society and economy. Albeit the profit maximation, all businesses must 
adhere to the principles of justice and fairness. In materialising the spirit of justice and fairness, Islam emphasize on ethical practices in all human activities including business activities. Ethical standards set by Islam include what is fair and just which are the nature of corporate responsibilities and standards of governance. Ethical business practices would enhance business prosperity and corporate accountability with ultimate objective for long term benefits to its shareholders and stakeholders. Thus, principles of corporate governance such as accountability, transparency and trustworthiness are not new under the Syariah. This is reflected from the concept of Shura (consultation) and Hisba (accountability).

The Quran has presented Shura as a principle of governance and a decision-making process which meet Islamic values such as justice and truthfulness. It involves disclosure and transparency as shura allows free and frank discussion among the members before reaching for a decision. It is emphasized that Shura is important as it not appropriate for one person to make decision which will affect other individuals. According to Maududi, the significant of shuratic decision making are:

i) In line with the concept of justice; those who make decision and those affected by a decision, should be involved in the decision making

ii) Consultation and consensus seeking prevent one group overriding others' rights

iii) Decision-making is an important trust from God and Islam demands from those holding this trust to practice justice, truthfulness \& consultation during group consultation

Hisbah on the other hand was an institution established in the early Abbasids to ensure compliance of the Shariah principles. The office known as Hisba and the office holder known as Muhtasib. The Muhtasib must be a person of high integrity, insight, reverence, in-depth knowledge.

The main purpose of Hisbah is to safeguard society from deviance, protect faith and ensure the welfare of the people in both religious and worldly manners according to the Shariah. Hisbah offers a framework of social ethics relevant to monitor corporation, with the objective to obligate the correct ethical behaviour in the wider social context and empower individual Muslims to act as private prosecutors in the cause of better governance by giving them a platform for social action. In relation to corporate governance, Hisbah would be monitoring the activities and forbid unethical behaviour in business dealings.

\section{Discussion and Recommendation}

The conventional corporate governance models are unsuitable for shari'ah corporate governance because the apex of shari'ah corporate governance is to obey God. Hence, it would be impossible to apply Islamic law by using conventional models of corporate governance structures which is based on worldviews which are inconsistent with Islamic law. In a model Shari'ah governance code which is applicable to all Islamic corporations, the following components shall be common, irrespective of their geographical location or localities.

\section{Independent of Shariah Board Committee}

Every Islamic company shall have an independent Shari'ah committee to supervise the activities and management of Islamic corporation. These scholars would be in a better position to advice on the doubtful activities happening in the company according to the vagaries of the economy. The job scope of this body would be to impartially advise and 
supervise all the activities happening in the company and to advice the Chief Executive Officer (CEO) of the company on the Islamicity of the affairs of the company. The decision of this committee wills be binding to followed by the management of the company.

\begin{abstract}
Shura
Shura is an Arabic term derived from a verb shawara. Shura is also related with the word Shara (Shara - Yashuru - Shawrun), which means "the exhibited, showed or displayed a thing" (Zain, Zulkarnain, \& Hassan, 2015). Technically, Shura is defined by Mahmud alKhalidi as "the meeting over something or issue as to ensure every person to ask another from such meeting for opinion of the concerned issue and to deduce a result from" (Dr. Mahmud Al-Khalidi, 1986). Shura is also defined as "mankind gathering towards concluding a truth by presenting some opinions of a problem so that they are guided to a resolution."

The type of involvement implicit in shuratic decision-making procedures provides a vehicle for ensuring that corporate activities and strategies are fully discussed and that a consensusseeking consultative process is applied. Directors and senior managers would be expected to listen to the opinions of other executives before making a decision and shura members would include, as far as possible, representatives of shareholders, employees, suppliers, customers and other interested parties(Lewis, 2005). The following two verses quoted from the primary source of Islamic law; the Holy Quran would be sufficient to prove this: And consult them on affairs (of moment). Then, when you have taken a decision, put your trust in Allah (3:159). Those who respond to their Lord and establish regular prayer; who (conduct) their affairs by mutual consultation; who spend out of what we bestow on them for sustenance (42:38).
\end{abstract}

Islam promotes Shura due to the benefits it gives to the mankind. For example, Shura would give the chance for the people who are most affected by the decision to participate and make a choice for them by discussing their own problems. Also, Shura would prevent the problem of one group of people overriding the rights of another like in the modern democratic rules where the majority of the people have all the saying; and the minority is left unattended as their voice is unreachable to the authorities. It is the duty imposed by God on the person in authority to seek advice from others when making group decisions (Mawdudi, 1974). This way the decision would be binding on all as the decision is not one person's and all would be satisfied. This is the key to creating a "win-win" situation.

\title{
Shariah Audit
}

The term audit comes from the Latin word audire, which means "to hear" or "to listen"(Flint, 1988). Auditing refers to a systematic and independent examination by evaluating evidence such as books, accounts, documents, and vouchers of an organisation to determine the accuracy of financial reporting and to communicate the result to the interested users(Ajao, Olamide, \& Ayodejitemitope, 2016). As cited by Akram , Cooper highlights that, the objectives of auditing is to report on the "truth and fairness of the financial position shown by the balance sheet, of the profit or loss shown by the profit and loss account and of any other information required to be disclosed in the financial accounts" (Muhammad Akram Khan, 1985).

In Islamic economy, accountability refers to transparency, producing a true and fair disclosure. True disclosure of financial facts and accurate information should be freely available, and this is needed for sound financial decision. This is where Hisbah play the role in the corporation; to safeguard society from deviance, protect faith and ensure the welfare of the people in both religious and worldly manners according to the Shariah 
The institution of hisba offers a framework of social ethics, relevant to monitor the corporation, with the objective of encouraging the correct ethical behaviour in the wider social context. It also empowers individual Muslims to act as 'private prosecutors' in the cause of better governance by giving them a platform for social action.it provides a device to solicit juristic advice, monitor compliance with Islamic precepts and collect zakah. This extra layer of auditing and accountability for resource use ensures that the enterprise operates as an Islamic concern (Lewis, 2005). Shari'ah audit shall be conducted at least once a year and details of the report shall be mentioned in the annual report of the corporation. In shari'ah corporate governance, there are two aspects of audit that must be included in the annual report, which are namely prudential audit and shari'ah audit. The auditing exercise for prudential aspect of the corporation would be conducted by authorized accountants and legal consultants. The shari'ah audit would be conducted by the Shari'ah Committee established within the corporation.(Muneeza \& Hassan, 2014)

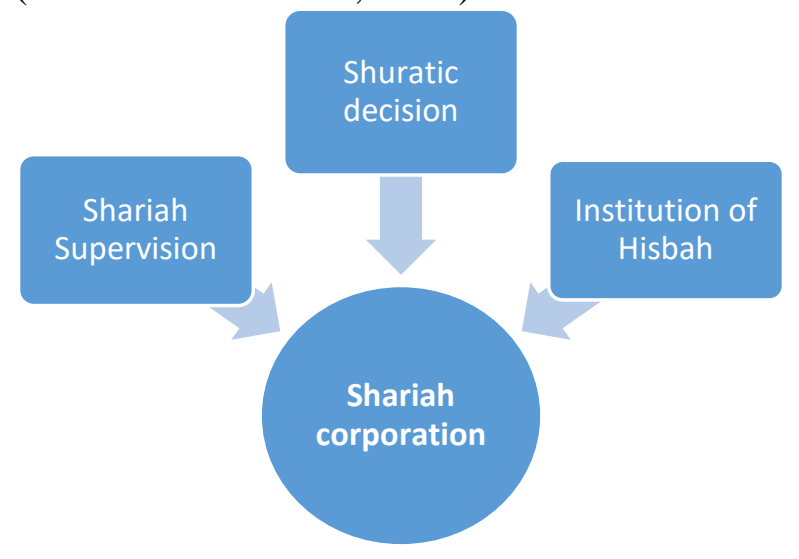

Figure 1: Summary of The Propose Governance Framework for Shariah Corporation

Conclusion

\begin{tabular}{|c|c|c|}
\hline & $\begin{array}{l}\text { CONVENTIONAL } \\
\text { GOVERNANCE }\end{array}$ & $\begin{array}{l}\text { SHARIAH } \\
\text { GOVERNANCE }\end{array}$ \\
\hline EPISTEME & rationalism/rationality & tawhid/oneness of God \\
\hline OBJECTIVES & $\begin{array}{l}\text { protect right and intersest of the } \\
\text { shareholders or /and stakeholder }\end{array}$ & $\begin{array}{l}\text { to protect the interest and } \\
\text { rights of all stakeholders but } \\
\text { subject to the rules of } \\
\text { Syariah }\end{array}$ \\
\hline $\begin{array}{l}\text { CORPORATE } \\
\text { GOAL }\end{array}$ & shareholders' profit/ social welfare & $\begin{array}{l}\text { profit oriented motive but in } \\
\text { accordance with syariah } \\
\text { objectives and principles }\end{array}$ \\
\hline MANAGEMENT & $\begin{array}{l}\text { board of directors/controlling } \\
\text { shareholders }\end{array}$ & $\begin{array}{l}\text { board of directors and } \\
\text { Syariah board commitee }\end{array}$ \\
\hline
\end{tabular}

Figure 2: The Comparison Between the Conventional and Shariah Governance

In view of the above differences, it is important to have a Shari'ah Corporate Governance framework to specifically govern the shariah corporations. Having specific Shari'ah corporate governance would definitely boost the public confidence on the shariah corporations. The Shari'ah Corporate Governance will enhance the role of the Shari'ah Boards, Board of Directors, management as well as the auditors of the Shariah Corporation. All of these organs 
of the shariah corporations shall execute their professional duties with the target of gratifying rules imposed by God and the expectations of all stakeholders. Definitely enacting a special Code would promote accountability, transparency, disclosure and clarity without prejudice. This is much closer to the spirit of Islam and is the way to create and manage governance and social responsibility. The viable critical success roots of this are yet to be examined with further research. Enacting a shari'ah corporate governance Code would definitely guide the companies that are classified as Shari'ah Corporation to operate their business in accordance with shariah principles.

\section{References}

Ajao, O. S., Olamide, J. O., \& Ayodejitemitope, A. (2016). Evolution and development of auditing. Unique Journal of Business Management Research, 3(1), 32-40.

Alam Choudhury, M., \& Ziaul Hoque, M. (2006). Corporate governance in Islamic perspective. Corporate Governance: The International Journal of Business in Society, 6(2), 116-128. https://doi.org/10.1108/14720700610655132

Choudhury, M. A., \& Hoque, M. Z. (2013). Corporate governance in Islamic perspective. International Journal of Islamic and Middle Eastern Finance and Management, 6(2), 180-199. https://doi.org/10.1108/14720700610655132

Dr. Mahmud Al-Khalidi. (1986). Nidzham Al-Shura Fi Al-Islam (1st Editio). Oman, Jordan: Maktabah Al-Risalah Al-Hadithah.

Fauziah, W., Yusoff, W., \& Alhaji, I. A. (2012). Insight of Corporate Governance Theories. Journal of Business \& Management, 1(1), 52-63. https://doi.org/10.5296/ajfa.v5i1.3210

Febianto, I. (2011). Shariah Compliant Model of Business Entities. Social Sciences, 1, 130149. Retrieved from http://papers.ssrn.com/sol3/papers.cfm?abstract_id=1891024

Fitzgeral, P. . (1966). Salmond on Jurisprudence. London: Sweet and Maxwell.

Flint, D. (1988). Philosophy and Principles of Auditing. Hampshire: Macmillan Education Ltd.

Lewis, M. K. (2005). Islamic Corporate Governance. Review of Islamic Economics, 9(1), 529.

Muhammad Akram Khan. (1985). Role of the auditor in an Islamic economy. Journal of Research in Islamic Economics, 3(1), 31-41.

Muneeza, A., \& Hassan, R. (2014). Shari'ah Corporate Governance: The Need for a Special Governance Code. Corporate Governance: The International Journal of Business in Society, 14(1), 120-129. https://doi.org/10.1108/CG-02-2011-0015

OECD. (2004). OECD Principles of Corporate Governance 2004.

Rashidah Abdul Rahman and Mohammad Rizal Salim. (2010). Corporate Governance in Malaysia. Sweet and Maxwell Asia.

Zain, N. R. B. M., Zulkarnain, I. F. B., \& Hassan, R. (2015). Shari'ah Corporate Governance Structure of Malaysian Islamic Banking and Finance: The Traces of Shura. Journal of Islamic Banking and Finance, 3(1), 26-34. https://doi.org/10.15640/jibf.v3n1a3

Zuryati, Z. a, Azrae, A. N., \& Yusoff, M. (2009). Separate legal entity under Syariah law and its application on Islamic banking in Malaysia: A note. The International Journal of Banking and Finance, 6(2), 139-154. 